\title{
DUA SISI AUDITING: AUDIT EKSTERNAL DAN INTERNAL PEMERINTAH
}

\author{
Two Side Auditing: Government External and Internal Audit
}

\section{Boby Segah}

Inspectorate of Central

Kalimantan, Palangka Raya,

Central Kalimantan, Indonesia

email: bobysegah@gmail.com

\section{Kata Kunci:}

Audit Internal

Audit Eksternal

Pemerintah

\section{Keywords:}

Internal Audit

External Audit

Government

Accepted

October 2018

Published

December 2018

\begin{abstract}
Abstrak
Di Indonesia, terdapat beberapa Lembaga Pengawasan, seperti Badan Pemeriksa Keuangan, Badan Pengawasan Keuangan dan Pembangunan, Inspektorat Jenderal dan Inspektorat di setiap Kementerian, Lembaga, Daerah Provinsi dan Daerah Kabupaten/Kota. Pihak institusi pemerintah yang diaudit sering mempertanyakan apa perbedaan dan persamaan di antara lembaga-lembaga pengawasan tersebut. Di samping itu mereka belum mengetahui mana lembaga audit eksternal dan lembaga audit internal Instansi Pemerintah di antara lembaga pengawasan tersebut. Banyak orang beranggapan, termasuk di kalangan institusi pemerintah yang menganggap bahwa setiap audit, siapapun pelaksananya sama saja. Yang mereka ketahui adalah setiap pemeriksa atau auditor kegiatannya sama. Semuanya meminjam banyak berkas, menguji setiap dokumen, memeriksa fisik, memeriksa uang kas/bank, banyak bertanya, dan yang lebih mereka pahami adalah semua auditor, yang bertugas untuk mencari temuan serta mencari masalah. Dari identifikasi masalah tersebut di atas dirumuskan permasalahan bahwa perlu adanya kejelasan tentang persamaan dan perbedaan antara audit eksternal dan internal di kalangan pemerintah.
\end{abstract}

\begin{abstract}
In Indonesia, there are several Supervisory Institutions, such as the Supreme Audit Agency, the Financial and Development Supervisory Agency, the Inspectorate General and the Inspectorate in each Ministry, Institution, Provincial Region and District / City Region. Audited government institutions often question what are the differences and similarities between the oversight institutions. In addition, they do not yet know which external audit institutions and internal audit institutions are Government Agencies among these oversight institutions. Many people assume, including among government institutions that assume that every audit, whoever is implementing it is the same. What they know is that each inspector or auditor has the same activities. Everything borrows a lot of files, tests every document, checks physically, check cash/banks, asks a lot, and what they understand more is all auditors, who are tasked with finding findings and finding problems. From the problem identified above, the problem is formulated that there needs to be clarity about the similarities and differences between external and internal audits in government circles.
\end{abstract}

\section{PENDAHULUAN}

Secara garis besar, audit dapat diartikan sebagai suatu pemeriksaan yang dilakukan secara kritis dan sistematis oleh pihak independent terhadap laporan keuangan yang telah disusun oleh manajemen beserta catatan pembukuan dan bukti pendukungnya (Agoes, 20I2). Proses auditing tersebut dilaksanakan oleh auditor, yaitu akuntan publik yang memberikan jasa kepada auditan untuk memeriksa laporan keuangan agar bebas dari salah saji (Mulyadi, 2013). Menurut Peraturan Menteri Negara Pendayagunaan Aparatur Negara Nomor PER/05/M.PAN/03/2008 tentang Standar Audit adalah sebagai berikut:
I. Audit asalah proses identifikasi masalah, analisis, dan evaluasi bukti yang dilakukan secara independen, obyektif, dan profesional berdasarkan standar audit untuk menilai kebenaran, kecermatan, kredibilitas, efektifitas, dan keandalan informasi pelaksanaan tugas dan fungsi instansi pemerintah.

2. Review adalah penelaahan ulang bukti-bukti suatu kegiatan untuk memastikan bahwa kegiatan tersebut telah dilaksanakan sesuai dengan ketentuan, standar, rencana atau norma yang telah ditetapkan.

3. Pemantauan adalah proses penilaian kemajuan suatu program/kegiatan dalam mencapai tujuan yang telah ditetapkan. 
4. Evaluasi adalah rangkaian kegiatan membandingkan hasil/prestasi suatu kegiatan dengan standar, rencana atau norma yang telah ditetapkan dan menentukan faktor-faktor yang mempengaruhi keberhasilan atau kegagalan suatu kegiatan dalam mencapai tujuan (Arens et al., 20l0).

Audit internal adalah aktivitas pemberian jasa konsultasi dan penjaminan yang bersifat independen dan obyektif yang bertujuan untuk menambah nilai dan menyempurnakan operasional organisasi. Audit internal membantu suatu organisasi mencapai sasarannya melalui evaluasi yang sistematis dan terencana dan meningkatkan efektivitas risk manajemen, pengendalian dan proses tata kelola. Pengawasan intern menurut Peraturan Pemerintah Republik Indonesia Nomor 60 Tahun 2008 tentang Sistem Pengendalian Intern Pemerintah adalah seluruh proses kegiatan audit, review, evaluasi, pemantauan dan kegiatan pengawasan lain terhadap penyelenggaraan tugas dan fungsi organisasi dalam rangka memberikan keyakinan yang memadai bahwa kegiatan telah dilaksanakan sesuai dengan tolok ukur yang telah ditetapkan secara efektif dan efisien untuk kepentingan pimpinan dalam mewujudkan tata kepemimpinan yang baik (Susilawati \& Atmawinata, 2014).

Setiap audit apapun jenisnya akan diakhiri dengan kesimpulan auditor atas pengujian fakta yang ditemui dengan kriterianya, dan setiap ketidaksesuaian akan dikemukakan dalam bentuk temuan dan rekomendasi untuk perbaikannya. Pihak yang harus menindaklanjuti rekomendasi adalah manajemen auditi. Di Indonesia, yang menjadi Auditor Eksternal Intansi Pemerintah adalah Badan Pemeriksa Keuangan Republik Indonesia. $\mathrm{Hal}$ ini terlihat dari setiap laporan pengelolaan dan tanggung jawab keuangan negara yang disusun pemerintah harus diaudit dulu oleh BPK RI sebelum disampaikan kepada Dewan Perwakilan Rakyat, Dewan Perwakilan Daerah, dan Dewan Perwakilan Rakyat Daerah sesuai dengan kewenangannya masing-masing.
Sumber hukum kewenangan BPK untuk memeriksa keuangan negara tersebut adalah Undang-Undang Dasar Negara Republik Indonesia Tahun 1945. Pasal 23E, UUD 1945 yang menyebutkan bahwa untuk memeriksa pengelolaan dan tanggung jawab tentang keuangan negara diadakan satu Badan Pemeriksa Keuangan yang bebas dan mandiri.

Berdasarkan Undang-undang Nomor 17 Tahun 2003 tentang Keuangan Negara, dalam pasal 30 dan 3 I maka Presiden menyampaikan Rancangan Undang-undang tentang Pertanggungjawaban Pelaksanaan APBN kepada DPR berupa Laporan Keuangan yang telah diperiksa oleh Badan Pemeriksa Keuangan selambat-lambatnya enam bulan setelah Tahun Anggaran berakhir. Laporan keuangan dimaksud dimaksud setidak-tidaknya meliputi Laporan Realisasi APBN, Neraca, Laporan Arus Kas dan Catatan atas Laporan Keuangan yang dilampiri dengan Laporan Keuangan Perusahaan Negara dan Badan lainnya. Seperti halnya untuk Pemerintah Pusat, maka Gubernur/Bupati/Walikota menyampaikan Rancangan Peraturan Daerah tentang Pertanggungjawaban Pelaksanaan APBD kepada DPRD berupa Laporan Keuangan yang telah diperiksa oleh BPK.

Bentuk dan isi Laporan Pertanggungjawaban Pelaksanaan APBN/APBD harus disusun dan disajikan sesuai dengan Standar Akuntansi Pemerintah yang disusun oleh Komite Standar yang independen dan ditetapkan dengan Peraturan Pemerintah setelah terlebih dahulu mendapat pertimbangan dari BPK. Pasal 33 Undang-undang tersebut mengamanatkan bahwa pemeriksaan pengelolaan dan pertanggungjawaban keuangan negara diatur dalam undang-undang tersendiri.

Undang-undang yang mengatur audit oleh BPK adalah Undang-undang Nomor I5 Tahun 2004 tentang Pemeriksaan Pengelolaan dan Tanggung Jawab Keuangan Negara. Pasal2 ayat (I) dan (2) Undangundang tersebut menyatakan bahwa "pemeriksaan keuangan negara yang dilakukan oleh BPK meliputi 
pemeriksaan atas pengelolaan keuangan negara dan pemeriksaan atas tanggung jawab keuangan negara”.

Aturan lebih detail tentang BPK terdapat dalam UndangUndang Republik Indonesia Nomor I5 Tahun 2006 tentang Badan Pemeriksa Keuangan. Dalam undangundang tersebut diatur tentang kedudukan dan keanggotaan, tugas dan wewenang BPK, pemilihan dan pemberhentian anggota dan pimpinan BPK, hak keuangan/administratif dan protokoler, tindakan kepolisian, kekebalan, larangan, kode etik, kebebasan, kemandirian dan akuntabilitas, pelaksana BPK, anggaran dan ketentuan pidana bagi Anggota BPK yang memperlambat atau tidak melaporkan hasil pemeriksaan yang mengandung unsur pidana, termasuk penyalahgunaan kewenangan. Dari hal tersebut dapat dilihat bahwa, audit yang dilaksanakan oleh BPK terhadap instansi pemerintah adalah audit oleh auditor di luar organisasi pemerintah atau Auditor Eksternal.

Jika diperhatikan, audit BPK terhadap Laporan Keuangan atau Laporan Pertanggungjawaban atas pelaksanaan APBN/APBD ditujukan untuk menilai hasil akhir dari pengelolaan keuangan pemerintah. Tujuan utama auditnya adalah untuk menilai dan memberikan pendapatan apakah Laporan Keuangan telah (I) mengikuti prinsip akuntansi yang berlaku umum, dan (2) menyajikan posisi keuangan organisasi secara wajar, (3) hasil usaha dalam suatu periode tertentu telah disajikan secara akurat, (4) apakah Laporan Keuangan telah memuat semua informasi yang bersifat (5) kinerja pemerintah telah sesuai dengan yang diharapkan secara ekonomis, efisien dan efektif (Sanger et al., 2016).

Pelaksanaan pemeriksaan oleh BPK harus mengacu kepada standar pemeriksaan keuangan negara. Standar pemeriksaan merupakan patokan bagi para pemeriksa dalam melakukan tugas pemeriksaannya. Standar pemeriksaan BPK diatur dalam Peraturan Badan Pemeriksa Keuangan Republik Indonesia Nomor 01 Tahun 2007 tentang Standar Pemeriksaan Keuangan Negara. Standar pemeriksaan yang dimaksud antara lain mengatur tanggung jawab manajemen entitas yang diperiksa, tanggung jawab pemeriksa, dan tanggung jawab organisasi pemeriksa dalam setiap pelaksanaan tugas pemeriksaan.

Dalam melakukan pemeriksaan keuangan, BPK RI sangat memperhatikan efektivitas internal control organisasi yang sedang diperiksanya. Hal ini ditegaskan dalam Lampiran III Peraturan BPK RI Nomor 0I Tahun 2007 tanggal 07 Maret 2007, standar pemeriksaan, pernyataan nomor 2 standar pelaksanaan pemeriksaan keuangan, hubungan dengan standar profesional akuntan publik IAI poin 03 b: "pemahaman yang memadai atas pengendalian intern harus diperoleh untuk merencanakan audit dan menentukan sifat, saat dan lingkup pengujian yang akan dilakukan”. Di samping itu, BPK RI sebagai institusi maupun pemeriksanya dalam melaksanakan penugasan juga wajib menaati kode etik. Kode etik yang berlaku di BPK diatur dalam Peraturan Badan Pemeriksa Keuangan Republik Indonesia Nomor 2 Tahun 2007 tentang Kode Etik Badan Pemeriksa Keuangan Republik Indonesia.

\section{METODOLOGI}

Sebagaimana telah dikemukakan pada pengertian audit internal di atas, audit dikalangan pemerintah dilakukan oleh auditor yang berada di lingkungan pemerintah, baik pemerintah pusat, provinsi maupun kabupaten/kota. Peraturan Pemerintah Nomor 60 Tahun 2008 tentang Sistem Pengendalian Intern Pemerintah menyatakan bahwa BPKP adalah Aparat Pengawasan Intern Pemerintah yang bertanggung jawab langsung kepada Presiden, Inspektorat Jenderal atau nama lain yang secara fungsional melaksanakan pengawasan intern adalah APIP yang bertanggung jawab langsung kepada Menteri/Pimpinan Lembaga, Inspektorat Provinsi adalah APIP yang bertanggung jawab langsung kepada Gubernur, dan Inspektorat Kabupaten/Kota adalah APIP yang bertanggung jawab langsung kepada Bupati/Walikota. Tujuan dibentuknya auditor internal di 
setiap jenjang pemerintahan tersebut adalah untuk membantu manajemen pemerintahan guna meningkatkan kinerja instansi pemerintah.

Dalam kaitannya dengan lingkungan pengendalian sebagai salah satu unsur dari Sistem Pengendalian Intern Pemerintah, perwujudan peran aparat pengawasan intern pemerintah yang efektif sangat diperlukan (pasal 4 huruf g, PP Nomor 60 Tahun 2008). Perwujudan peran aparat pengawasan intern pemerintah yang efektif dalam membantu meningkatkan kinerja manajemen tersebut sekurang-kurangnya harus memberikan keyakinan yang memadai atas ketaatan, kehematan, efisiensi dan efektivitas pencapaian tujuan penyelenggaraan tugas dan fungsi instansi pemerintah, memberikan peringatan dini dan meningkatkan efektivitas manajemen resiko dalam penyelenggaraan tugas dan fungsi instansi pemerintah, dan memelihara dan meningkatkan kualitas tata kelola penyelenggaraan tugas dan fungsi instansi pemerintah.

Peran APIP dalam membantu manajemen institusi pemerintah juga diatur dalam berbagai peraturan lainnya. Peraturan Pemerintah Nomor 54 Tahun 2010 tentang Pengadaan Barang/Jasa Pemerintah mewajibkan pimpinan intitusi pemerintah untuk melakukan pengawasan terhadap PPK dan ULP/Pejabat Pengadaan di lingkungan K/L/D/I (Kementerian, Lembaga, Daerah dan Instansi) dan menugaskan aparat pengawas intern yang bersangkutan untuk melakukan audit.

Undang-Undang Nomor 32 Tahun 2004 tentang Pemerintahan Daerah, pasal 218 menetapkan bahwa pengawasan atas penyelenggaraan pemerintahan daerah dilaksanakan oleh aparat pengawas intern yang meliputi pengawasan atas pelaksanaan urusan pemerintahan di daerah, pengawasan terhadap peraturan daerah dan peraturan kepala daerah. Pasal 9 Undang-undang Nomor 15 Tahun 2004 tentang Pemeriksaan Pengelolaan dan Tanggung Jawab Keuangan Negara juga menyebutkan bahwa menyelenggarakan pemeriksaan pengelolaan dan tanggaung jawab keuangan negara, BPK dapat memanfaatkan hasil pemeriksaan aparat pengawasan intern pemerintah dan laporan hasil pemeriksaannya wajib disampaikan kepada BPK.

Dalam setiap melaksanakan tugas audit, auditor internal juga wajib melaksanakannya sesuai dengan standar audit. Bahkan di dalam setiap menulis laporan hasil audit, auditor wajib mencantumkan satu kalimat di dalam laporannya bahwa audit telah dilaksanakan sesuai dengan standar audit. Standar audit internal, antara lain diatur dalam Peraturan Menteri Negara Pendayagunaan Aparatur Negara Nomor PER/05/M.PAN/03/2008 tentang Standar Audit, Keputusan Kepala BPKP Nomor KEP-378/K/I998 tanggal 30 Mei 1996 tentang Penetapan Berlakunya Standar Audit Aparat Pengawasan Fungsional Pemerintah, dan Keputusan Dewan Pengurus Nasional Asosiasi Auditor Intern Pemerintah Indonesia Nomor Kep005/AAIPUDPN/20I4 tanggal 24 April 2014 tentang Pemberlakuan Kode Etik Auditor Intern Pemerintah Indonesia, Standar Audit Intern Pemerintah Indonesia dan Pedoman Telaah Sejawat Auditor Intern Pemerintah Indonesia.

Kecuali harus sesuai dengan standar audit, auditor internal juga diwajibkan untuk selalu berperilaku yang baik. Hal ini diatur dalam Kode Etik Auditor. Prinsip kode etik adalah mengatur perilaku dalam setiap melaksanakan audit agar auditor tetap menjaga integritas, obyektif, kerahasiaan dan meningkatkan kompetensinya. Kode etik di lingkungan auditor internal pemerintah antara lain diatur dalam Peraturan Menteri Pendayagunaan Aparatur Negara Nomor PER/04/M.PAN/03/2008 tentang Kode Etik Aparat Pengawasan Intern Pemerintah, Aturan Perilaku Pemeriksa BPKP yang diterbitkan oleh Badan Pengawas Keuangan dan Pembangunan Tahun 1993, Kode Etik Auditor Intern Pemerintah Indonesia sesuai Surat Ketua Komite Kode Etik AAIPI Nomor S-0I/AAIPI/3/20I4 tanggal 6 Maret 2014 tentang Kode Etik. 


\section{HASIL DAN PEMBAHASAN}

Auditor Internal maupun Auditor Eksternal memainkan peran masing-masing yang penting dalam tata kelola suatu organisasi. Walaupun memiliki berbagai persamaan, internal auditing memiliki perbedaan yang jelas dari eksternal auditing, seperti diuraikan berikut ini:

Persamaan antara Audit Eksternal dan Audit Internal Pemerintah

Dari uraian pada Bab-bab terdahulu dapat diketahui beberapa persamaan antara audit eksternal dan audit internal dikalangan pemerintah. Beberapa persamaan tersebut diantaranya sebagai berikut:

I. Membandingan antara fakta yang dijumpai di pihak auditi dengan kriterianya

Pada dasarnya setiap audit dilakukan dengan cara membandingkan fakta-fakta yang dijumpai auditor dengan kriterianya. Dalam rangka melakukan pembandingan antara fakta dengan kriterianya auditor terlebih dahulu melakukan pengujian efektivitas sistem pengendalian intern. Tingkat efektivitas sistem pengendalian intern menjadi pegangan bagi auditor untuk menentukan luasnya (banyaknya sampel) pengujian. Pengujian dilakukan untuk pembuktian setiap tujuan audit yang diperlukan untuk pembandingan antara fakta dan kriterianya. Dari pembandingan ini auditor akan mengetahui apakah fakta yang ada telah sesuai atau tidak dengan kriterianya. Jika fakta telah sesuai dengan kriteria, berarti auditi telah dapat merealisasikan tugas pokok dan fungsinya. Namun jika fakta yang ada berbeda atau bertentangan dengan kriterianya, hal ini menunjukkan auditi tidak atau belum dapat melaksanakan tugas-tugasnya dengan baik, atau ada penyimpangan. Jika terjadi demikian, maka auditor mengembangkan oerbedaan tersebut dalam bentuk temuan. Untuk ini auditor mencari penyebab terjadinya perbedaan dan dampak yang ditimbulkannya.

Selanjutnya auditor menimbang secara profesional materialitas atau signifikasi dampak dampak yang terjadi. Jika dampak yang timbul cukup material atau signifikan, berarti penyimpangan perlu segera diperbaiki. Sebaliknya, jika dampak penyimpangannya tidak signifikan, mungkin perbaikannya tidak terlalu mendesak. Dengan mengetahui seberapa besar dampak dan penyebab penyimpangan, auditor akan dapat memberikan saran untuk perbaikannya.

Auditor eksternal yang melakukan audit atas laporan keuangan akan memberi opini Wajar Tanpa Pengecualian, jika laporan keuangan telah disusun sesuai dengan standar akuntansinya. Hal ini menunjukkan bahwa praktik manajemen dalam menyusun laporan keuangan telah baik dan dapat diteruskan untuk periode berikutnya. Sebaliknya jika laporan keuangan mengandung penyimpangan dari standar akuntansinya maka opininya adalah Wajar Dengan Pengecualian. Jika penyimpangannya semakin material, berarti manajemen telah salah dalam menerapkan standar akuntansi. Dalam hal ini auditor memberi opini Tidak Wajar. Adakalanya auditor tidak dapat mengumpulkan cukup bukti audit tentang suatu penyajian dalam laporan keuangan yang membuat auditor memberi opini disclaimer (Tidak Memberi Opini).

Auditor internal dalam membatasi luasnya sampel juga berpegang kepada kesimpulannya atas efektivitas sistem pengendalian intern yang berjalan pada kegiatan atau program sasaran auditnya. Auditor internal yang melakukan audit kinerja akan menguji apakah auditi telah melaksanakan program dan atau kegiatannya secara ekonomis, efisien dan efektif (3E). Jika pelaksanaan program atau kegiatan yang menjadi sasaran audit telah memenuhi tiga aspek tersebut, berarti auditi telah melaksanakan 
tugas dan fungsinya secara baik. Jika demikian, auditor tidak perlu menyampaikan temuan dan rekomendasi untuk perbaikannya. Dengan demikian auditi dapat meneruskan pelaksanaan program dan kegiatannya pada periode berikutnya. Namun jika auditor masih menemukan kekurangan pada salah satu atau seluruh aspek $3 \mathrm{E}$ tersebut, berarti auditi dalam melaksanakan tugas pokok dan fungsinya masih ada kekurangan. Untuk ini auditor menyampaikan temuan disertai dengan rekomendasinya.

2. Berpedoman pada standar audit

Baik auditor eksternal maupun auditor internal pemerintah harus mempedomani standar audit masing-masing dalam pelaksanaan audit. Standar audit yang mengatur APIP dalam melaksanakan audit adalah Peraturan Menteri Pendayagunaan Aparatur Negara Nomor PER/05/M.PAN/03/2008 tentang Standar Audit Aparat Pengawasan Intern Pemerintah dan Keputusan Dewan Pengurus Nasional Asosiasi Auditor Intern Pemerintah Indonesia Nomor KEP-005/AAIPUDPN/20I4 tanggal 24 April 2014 tentang Pemberlakuan Kode Etik Auditor Intern Pemerintah Indonesia, Standar Audit Intern Pemerintah Indonesia dan Pedoman Telaah Sejawat Auditor Intern Pemerintah Indonesia. Dan pedoman pelaksanaan audit bagi BPK RI selaku auditor eksternal pemerintah adalah Peraturan Badan Pemeriksa Kauangan Republik Indonesia Nomor 0I Tahun 2007 tentang Standar Pemeriksaan Keuangan Negara.

Pada dasarnya, auditor dalam melaksanakan audit harus menerapkan berbagai prosedur yang sesuai dengan keadaannya. Seluruh prosedur yang ditempuh harus dalam rangka meyakinkan bahwa fakta-fakta memang sesuai dari kriterianya, atau sebaliknya. Dengan standar yang demikian, maka simpulan, temuan dan hal-hal penting yang dijumpai auditor dapat diandalkan kebenarannya.
3. Taat pada kode etik profesi auditor

Peraturan Badan Pemeriksa Keuangan Republik Indonesia Nomor 2 Tahun 201 I tentang Kode Etik Badan Pemeriksa Keuangan pasal I angka 12 menyatakan bahwa Kode Etik BPK yang selanjutnya disebut Kode Etik adalah norma-norma yang harus dipatuhi oleh setiap Anggota BPK, Pemeriksa dan Pelaksana BPK lainnya selama menjalankan tugasnya untuk menjaga martabat, kehormatan, citra dan kredibilitas BPK. Kode etik dimaksud menjadi pedoman yang wajib ditaati oleh Anggota BPK, Pemeriksa dan Pelaksana BPK lainnya selaku individu dan anggota masyarakat, selaku warga negara, anggota BPK selaku Pejabat Negara dan Pemeriksa serta Pelaksana BPK lainnya selaku Aparatur Negara. Senada dengan kode etik BPK, APIP juga memiliki kode etik Aparat Pengawasan Intern Pemerintah yang diatur dengan Peraturan Menteri Negara Pendayagunaan Aparatur Negara Nomor PER/04/M.PAN/03/2008 tentang Kode Etik Aparat Pengawasan Intern Pemerintah yang menyatakan dalam diktum kedua yaitu Kode Etik Aparat Pengawasan Intern Pemerintah sebagaimana dimaksud pada diktum pertama wajib dipergunakan sebagai acuan untuk mencegah terjadinya tingkah laku yang tidak etis, sehingga terwujud auditor yang kredibel dengan kinerja yang optimal dalam pelaksanaan audit. Kode Etik Auditor Intern Pemerintah Indonesia juga sesuai dengan Surat Ketua Komite Kode Etik AAIPI Nomor S0I/AAIPI/3/20I4 tanggal 06 Maret 2014 tentang Kode Etik.

4. Independen terhadap kegiatan yang diaudit

Agar pelaksanaan audit berjalan secara obyektif, maka pegawai dan lembaga audit internal maupun audit eksternal harus independen dari kegiatan yang diauditnya. Independensi BPK dinyatakan dalam Standar Pemeriksaan Keuangan Negara pada bagian pernyataan standar umum kedua yang berbunyi 
“dalam semua hal yang berkaitan dengan pekerjaan pemeriksaan, organisasi pemeriksa dan pemeriksa harus bebas dalam sikap mental dan penampilan dari gangguan pribadi, ekstern dan organisasi yang dapat mempengaruhi independensinya”.

Independensi APIP diatur dalam paragraf 1100 Standar Audit Auditor Intern Instansi Pemerintah Indonesia - Independensi dan obyektivitas yang menyatakan "dalam semua hal yang berkaitan dengan penugasan audit intern, APIP dan kegiatan audit intern harus independen serta para auditornya harus obyektif'. Demikian juga dalam paragraf 21 10 Standar Audit Aparat Pengawasan Internal Pemerintah, yang berbunyi "Pimpinan APIP bertanggung jawab kepada Pimpinan tertinggi organisasi agar tanggung jawab pelaksanaan audit dapat terpenuhi”. Dengan kata lain posisi APIP harus ditempatkan secara tepat sehingga bebas dari intervensi dan memperoleh dukungan yang memadai dari Pimpinan tertinggi organisasi, sehingga dapat bekerja sama dengan auditi dan melaksanakan pekerjaan dengan leluasa.

Meskipun demikian, APIP harus membina hubungan kerja yang baik dengan auditi, terutama dalam saling memahami diantara peranan masing-masing lembaga.

Perbedaan antara Audit Eksternal dan Audit Internal Pemerintah

Dari uraian pada Bab-bab terdahulu diketahui ada tiga perbedaan antara audit eksternal dan audit internal dikalangan pemerintah. Perbedaan tersebut berkaitan dengan pendekatan yang berbeda, struktur organisasi lembaga audit, dan persyaratan menjadi auditor. Di bawah ini diuraikan perbedaan-perbedaan tersebut.

\section{Pendekatan yang berbeda}

Auditor internal dalam instansi publik memberi penekanan dalam pemberian jaminan atas kinerja dan kepatuhan terhadap suatu kebijakan dan prosedur tertentu. Berkenaan dengan semua aspek organisasi, baik finansil maupun non financiil, auditor internal berfokus dengan pendekatan pada kebijakan masa depan, sebagai hasil dari reviu berkelanjutan dan evaluasi atas proses dan pengendaliannya.

Pada sisi yang lain, auditing eksternal memberikan opini independen atas kewajaran penyajian laporan keuangan suatu organisasi. Jenis audit ini mencakup pertanyaan, apakah laporan keuangan mengikuti prinsip akuntansi yang berlaku umum, apakah laporan keuangan menyajikan posisi keuangan organisasi secara wajar, apakah hasil usaha dalam suatu periode tertentu telah disajikan secara akurat, dan apakah laporan keuangan telah memuat semua informasi yang bersifat material (yakni apakah laporan keuangan memuat kesalahan penyajian yang mungkin mempengaruhi keputusan ekonomi dari pengguna laporan keuangan).

Pendekatan yang digunakan oleh audit eksternal pada umumnya adalah yang bersifat historis (sesuatu yang telah terjadi) walaupun saran-saran kepada manajerial memuat penyempurnaanpenyempurnaan untuk ke depan berdasarkan hasil analisa atas pengendalian yang berlaku pada saat audit laporan keuangan dilakukan.

Audit internal mencakup lebih luas dan lebih banyak hal dibandingkan audit eksternal. Nilai lebih audit internal terletak pada kemampuannya untuk menilai operasi yang berhubungan dengan angka-angka finansil tertentu sebelum angka tersebut akhirnya masuk dalam pembukuan perusahaan. Contoh : ketika berbicara tentang "penjualan" sebagai suatu perkiraan dalam laporan keuangan, audit eksternal terutama meneliti eksistensi, kelengkapan bukti penjualan, akurasi, klasifikasi, waktu, posting dan pengikhtisaran angka penjualan. Audit internal melihat lebih jauh dibalik penyajian angka penjualan dimaksud, dan memperhatikan operasi penjualan dalam konteks yang lebih luas dengan bertanya 
tentang : target pasar, rencana penjualan, struktur organisasi bagian penjualan, kualifikasi personil, efektifitas usaha penjualan, pengukuran kinerja penjualan dan kepatuhan terhadap kebijakan penjualan. Pertanyaan-pertanyaan ini menggali hingga ke dalam inti usaha penjualan yang sangat mempengaruhi angka penjualan dalam laporan keuangan. Contoh misalkan angka penjualan sebesar US\$ 6 juta, auditor eksternal hanya memberi pendapat tentang keabsahan angka tersebut. Namun auditor internal bertanya bukankah angkanya seharusnya US\$ 12 juta jika saja penentuan pasar yang menjadi sasaran lebih tepat, dan jika usaha penjualan berjalan lebih efektif.

\section{Struktur Organisasi}

Auditor internal merupakan bagian dari suatu organisasi - klien (pengguna jasa) utama mereka adalah manajemen dan direksi/dewan komisaris. Walaupun secara historis auditor internal awalnya bertanggungjawab kepada direktur keuangan (pejabat tertinggi bidang keuangan) ataupun pejabat tinggi lain dalam perusahaan, kecenderungan saat ini auditor internal bertanggungjawab secara langsung kepada direktur utama, sehingga memperkuat independensi dan obyektifitasnya. Kebanyakan fungsi internal audit yang ada sekarang ini mengikuti struktur pertanggungjawaban seperti ini, yang konsisten dengan Standar IIIO tentang independensi dari The Institute of Internal Auditors.

Sebaliknya auditor eksternal bukan bagian organisasi, tetapi diberi tugas oleh organisasi atau ketentuan perundang-undangan yang berlaku. Sasaran kerja mereka terutama ditetapkan oleh undang-undang dan kebutuhan klien utama mereka. Auditor eksternal dipilih dan ditugaskan oleh undang-undang yang berlaku oleh Direksi BUMN dan mereka menghasilkan suatu laporan tahunan bagi DPR atau DPRD atau Pemegang Saham Perusahaan. Penunjukan auditor eksternal suatu
Badan Usaha dimaksudkan untuk jangka waktu tertentu, dan bisa dipilih lagi dalam Rapat Umum Pemegang Saham Perusahaan. Dalam peraturan berbagai negara, pengguna jasa auditor eksternal yang sama dibatasi jangka waktunya, biasanya 5 atau 7 tahun.

Seperti telah diuraikan di atas, audit eksternal oleh auditor dari luar organisasi auditi, sedangkan audit internal dilakukan oleh auditor dari dalam organisasi auditi. Secara mudah dapat dikemukakan bahwa jika auditornya adalah BPK, maka audit tersebut adalah audit eksternal. Sedangkan jika auditornya adalah Inspektorat Jenderal atau nama lain, maka audit tersebut adalah audit internal.

Termasuk di dalam audit internal adalah audit pada institusi pemerintah oleh BPKP. Sekalipun BPKP tidak berada pada organisasi kementerian, lembaga atau pemerintah daerah, namun BPKP berada di lingkungan pemerintah yakni di bawah Presiden. Dengan demikian audit yang dilakukan oleh BPKP masih tergolong audit internal.

3. Persyaratan menjadi Auditor (Bekualifikasi dan Berpengetahuan)

Kualifikasi yang dibutuhkan oleh auditor tergantung dari pertimbangan pimpinannya. Walaupun biasanya auditor internal adalah akuntan, sebagian adalah insinyur, pegawai penjualan, insinyur produksi, pegawai lain yang pernah bertugas dan telah berpengalaman tentang operasi yang mau di audit sehingga diyakini mampu melaksanakan audit internal.

Standar 2200 dari Standar Audit APIP mensyaratkan bahwa auditor harus mempunyai pengetahuan, keterampilan dan kompetensi lainnya yang diperlukan untuk melaksanakan tanggung jawabnya. Pemeriksaan seluruh sistem operasi organisasi secara berkelanjutan, auditor internal yang telah bekerja beberapa tahun di dalam suatu organisasi 
tentulah mengetahui secara luas tentang organisasi dan operasinya.

Auditor eksternal harus mengetahui errors dan irregularities, tahu menilai kemungkinan terjadinya, mampu merencanakan audit untuk memberi keyakinan terdeteksinya hal tersebut yang bersifat material dan melaporkannya. BPK dalam Standar Pemeriksaan Keuangan Negara, Pernyataan Standar Pemeriksaan 0I Standar Umum menetapkan bahwa "pemeriksaan secara kolektif harus memiliki kecakapan profesional yang memadai untuk melaksanakan tugas pemeriksaan”. Kecakapan prosesional yang memadai diharapkan dapat diperoleh dari adanya persyaratan tingkat pendidikan formal pada waktu penerimaan calon pegawai, disamping auditor BPK juga harus mengikuti Persyaratan Pendidikan Berkelanjutan.

Auditor perusahaan publik sebagai auditor eksternal juga harus menjadi anggota organisasi profesi akuntan yang diakui undang-undang yakni Institut Akuntan Publik Indonesia (IAPI). Karena lingkup pekerjaan auditor eksternal dipersempit hanya untuk audit laporan keuangan dan mereka mengunjungi organisasi yang diaudit sekali atau dua kali dalam setahun, pengetahuan mereka tentang operasional organisasi yang diauditnya kemungkinan tidak seluas pemahaman auditor internal.

\section{KESIMPULAN}

Dari uraian pada Bab-bab terdahulu dapat disimpulkan bahwa antara audit eksternal dan internal memang ada permasalahan dan berbedaannya. Beberapa persamaannya diantaranya melakukan pembandingan antara fakta-fakta dengan kriterianya, berpedoman pada standar audit, perilaku auditornya harus taat pada kode etik profesi, dan independen terhadap kegiatan yang diaudit. Perbedaan antara keduanya terletak pada pendekatan yang berbeda dalam pelaksanaan auditnya, struktur organisasi lembaga audit, dan persyaratan menjadi auditor. Auditor internal dalam Instansi Publik memberi penekanan dalam pemberian jaminan atas kinerja dan kepatuhan terhadap suatu kebijakan dan prosedur tertentu. Auditor internal berfokus dengan pendekatan pada kejadian masa depan, sebagai hasil dari reviu berkelanjutan dan evaluasi atas proses dan pengendaliannya. Pada sisi yang lain, auditing eksternal memberikan opini independen atas kewajaran penyajian laporan keuangan organisasi yang diauditnya. Audit eksternal dilakukan oleh auditor yang berasal dari dalam organisasi auditi, sedangkan audit internal dilakukan oleh auditor yang berasal dari dalam organisasi auditi. Audit eksternal menilai hasil akhir (output) dari kegiatan atau program yang diaudit, sedangkan audit internal membantu manajemen sejak sebelum, selama dan setelah kegiatan dilakukan. Audit internal memberikan nilai tambah bagi manajemen dalam bentuk audit, reviu, evaluasi, pemantauan dan kegiatan lainnya. Seluruh kegiatan tersebut ditujukan untuk memberikan jaminan mutu bahwa tujuan-tujuan auditi dapat direalisasikan secara ekonimis, efisien dan efektif. Dalam kenyataannya, masih sering audit internal pemerintah melakukan auditnya seperti audit eksternal, yaitu hanya mengaudit hasil akhir dari pelaksanaan program atau kegiatan auditi.

\section{REFERENSI}

Agoes, S. 2012. Auditing: Petunjuk Praktis Pemeriksaan Akuntan oleh Akuntan Publik. Jakarta: Salemba Empat.

Arens, A.A., Beasley, M.S., \& Elder, R.J. 2010. Auditing and Assurance Service, An Integrated Approach $19^{\text {th }}$ Edition. New Jersey: Global Edition.

Mulyadi. 20I3. Auditing. Jakarta: Salemba Empat.

Peraturan Badan Pemeriksa Keuangan Republik Indonesia Nomor 0I Tahun 2007 tentang Standar Pemeriksaan Keuangan Negara.

Peraturan Menteri Negara Pendayagunaan Aparatur Negara No. PER/05/M.PAN/03/2008 tentang Standar Audit. 
Peraturan Pemerintah Nomor 60 Tahun 2008 tentang Sistem Pengendalian Intern Pemerintah.

Peraturan Pemerintah Republik Indonesia Nomor 7I Tahun 2010 tentang Standar Akuntansi Pemerintahan.

Sanger, C.L., Ilat, V., \& Pontoh, W. 2016. Pengaruh Pengalaman Audit, Keahlian Audit dan Tekanan Ketaatan terhadap Audit Judgment BPK RI Perwakilan Provinsi Sulawesi Utara. Jurnal Accountability. 5(2): I I-22.

Susilawati \& Atmawinata, M.R. 2014. Pengaruh Profesionalisme dan Independensi Auditor Internal terhadap Kualitas Audit: Studi pada Inspektorat Propinsi Jawa Barat. Jurnal Etikonomi. 13(2): I90-210.

Undang - Undang Republik Indonesia Nomor 17 Tahun 2003 tentang Keuangan Negara.

Undang - Undang Republik Indonesia Nomor I 5 Tahun 2004 tentang Pemeriksaan Pengelolaan dan Tanggung Jawab Keuangan Negara.

Undang - Undang Republik Indonesia Nomor 15 Tahun 2006 tentang Badan Pemeriksa Keuangan. 